grown steadily with a membership of 88 National Trade Union Confederations from 37 countries and ten European Industry Federations with a total of $60 \mathrm{~m}$. members. The Congress meets every four years; the 13th Statutory Congress took place in Paris in Sept.-Oct. 2015.

Address: 5 Blvd Roi Albert II, B-1210 Brussels, Belgium.

Website: http://www.etuc.org

Email: etuc@etuc.org

General Secretary: Luca Visentini (Italy).

\section{Alliance of Small Island States (AOSIS)}

The Alliance of Small Island States was established in 1990 by a coalition of small island and low-lying coastal nations. It seeks to co-ordinate members' lobbying efforts within the United Nations system in relation to the environmental and developmental challenges facing them-especially the adverse effects of climate change.

Organization. The AOSIS has no formal charter or permanent secretariat. However, there is a Bureau, made up of the chairperson and two vice-chairs, appointed from the UN Permanent Representatives of countries from each of the organization's three regional groupings (the Caribbean; the Pacific; and Africa, Indian Ocean, Mediterranean and South China Sea).

Members. As of Feb. 2016 AOSIS comprised 37 nation states (plus the New Zealand dependencies of the Cook Islands and Niue): Antigua and Barbuda, Bahamas, Barbados, Belize, Cabo Verde, Comoros, Cuba, Dominica, Dominican Republic, Fiji, Federated States of Micronesia, Grenada, Guinea-Bissau, Guyana, Haiti, Jamaica, Kiribati, Maldives, Marshall Islands, Mauritius, Nauru, Palau, Papua New Guinea, St Kitts and Nevis, St Lucia, St Vincent and the Grenadines, Samoa, Singapore, Seychelles, São Tomé e Príncipe, Solomon Islands, Suriname, Timor-Leste, Tonga, Trinidad and Tobago, Tuvalu and Vanuatu. A further five nonsovereign territories have observer status.

Website: http://aosis.org

Chairperson: Ahmed Sareer (Maldives).

\section{Amnesty International (AI)}

Origin. Founded in 1961 by British lawyer Peter Benenson as a one-year campaign for the release of prisoners of conscience, Amnesty International has grown to become a worldwide organization, winning the Nobel Peace Prize in 1977.

Activities. AI is a worldwide movement of people campaigning for human rights. It acts independently and impartially to promote respect for internationally recognized human rights standards.

Historically, the focus of AI's campaigning has been: to free all prisoners of conscience (a term coined by Peter Benenson); to ensure a prompt and fair trial for all political prisoners; to abolish the death penalty, torture and other cruel, inhuman or degrading punishments; to end extrajudicial executions and 'disappearances'; to fight impunity by working to ensure perpetrators of such abuses are brought to justice. AI is independent of any government or political ideology, and neither supports nor opposes the views of the victim it seeks to protect.
AI has over $3 \mathrm{~m}$. members, subscribers and regular donors in more than 150 countries. Major policy decisions are taken by an International Council comprising representatives from all national sections. AI's national sections, members and supporters are primarily responsible for funding the movement. In 2012 the Amnesty International movement's total income was $£ 225,340,000$.

Every year AI produces a global report detailing human rights violations in all regions of the world.

International Secretariat: Peter Benenson House, 1 Easton St., London WC1X 0DW, UK.

Website: http://www.amnesty.org

Secretary-General: Salil Shetty (India).

\section{Further Reading}

Power, Jonathan, Like Water on Stone: The Story of Amnesty International. 2001

\section{Bank for International Settlements (BIS)}

Origin. Founded on 17 May 1930, the Bank for International Settlements is the world's oldest international financial organization.

Activities. The BIS fosters international monetary and financial co-operation and serves as a bank for central banks. It acts as a forum to promote discussion and policy analysis among central banks and within the international financial community, a centre for economic and monetary research and an agent or trustee in connection with international financial operations.

As its customers are central banks and international organizations, the BIS does not accept deposits from, or provide financial services to, private individuals or corporate entities.

The head office is in Basle, Switzerland, and there are representative offices in Hong Kong and Mexico City.

Representative Office for Asia and the Pacific: 78th Floor, Two International Finance Centre, 8 Finance St., Central, Hong Kong SAR, People's Republic of China.

Representative Office for the Americas: Torre Chapultepec, Rubén Dario 281, Col. Bosque de Chapultepec, 11580 México, D. F., Mexico.

Headquarters: Centralbahnplatz 2, CH-4051 Basle, Switzerland. Website: http://www.bis.org

Email: email@bis.org

Chairman of the Board of Directors: Jens Weidmann (Germany).

\section{Further Reading}

Yago, Kazuhiko, The Financial History of the Bank for International Settlements. 2012

\section{Commonwealth}

The Commonwealth is a free association of sovereign independent states. It numbered 53 members in Feb. 2016. With a membership of over $2 \mathrm{bn}$. people, it represents around $30 \%$ of the world's population. There is no charter, treaty or constitution; the association is expressed in co-operation, consultation and mutual assistance for which the Commonwealth Secretariat is the central co-ordinating body. 